\title{
Aerobic and Anaerobic Bacterial Interactions in the Development of Anaerobic Bacterial Pneumonia
}

\author{
Jun GOTO \\ Department of Internal Medicine, Oita Medical University \\ Present address: Department of Raspiratory Disease, National Oita Hospital
}

(Received: July 22, 1992)

(Accepted: October 20, 1992)

Key words: anaerobic bacterial pneumonia, Bacteroides fragilis, mixed infec-

tion, phagocytosis

\begin{abstract}
Summary
The interactions between aerobic and anaerobic bacteria in the development of anaerobic bacterial pneumonia were studied by introducing Bacteroides fragilis and Escherichia coli alone or in combination into guinea pigs by tracheal infusion. The lung lesions induced by $B$. fragilis were mainly located near the pleura, unlike those induced by $E$. coli, and were accompanied by pneumonia, lung abscess, and pleuritis. The lung lesions produced by mixed infection with $B$. fragilis $\left(10^{9} \mathrm{cfu}\right)$ and $E$. coli $\left(10^{7} \mathrm{cfu}\right)$ were significantly more severe than those induced by either microbe alone, and the redox potentials at the foci of inflammation were markedly reduced (max: $-330 \mathrm{mV}$ ). Analysis of lung lesions after treatment with aztreonam and clindamycin and neutrophil phagocytic activity suggested that $E$. coli was primarily responsible for the lung lesions and that $B$. fragilis promoted the accompanying inflammation, resulting in increased pathogenicity of the mixed infections.
\end{abstract}

\section{Introduction}

Non-spore forming anaerobes (anaerobic bacteria) are important pathogens in respiratory infections such as lung abscess, pyothorax, and aspiration pneumonia, which are often encountered in clinical practice $^{1 / 2)}$. Anaerobic bacterial infections are usually found as mixed infections in combination with aerobic bacteria ${ }^{1)}$, and synergism between them has been found in both in vitro and in vivo experiments ${ }^{3 / 4}$. In animals, anaerobic bacterial infections are often induced by intraperitoneal, subcutaneous or intracutaneous inoculation ${ }^{56 / 7)}$, but experimental pulmonary infections are scarce, probably because of the high oxygen pressure and rich blood flow in the lung.

In this study, we induced pneumonia by directly infusing bacterial suspensions into the guinea pig trachea, using Bacteroides fragilis strains which are the most frequent pathogens implicated in anaerobic bacterial infections. The interactions between aerobic and anaerobic bacteria in formation of lung lesions were evaluated, using Escherichia coli as a representative aerobe. Mixed bacterial pneumonia was found to be more severe and more resistant to antibiotic treatment than pneumonia due to either B. fragilis or $E$. coli alone, indicating synergism between the two bacterial species in lung lesions. B. fragilis is assumed to enhance the pathological changes caused by $E$. coli.

別刷請求先：（元870-02）大分市大字横田1000-1

国立大分病院呼吸器科後藤 純 


\section{Materials and Methods}

\section{Bacterial strains}

The anaerobic bacteria employed in this study were superoxide dismutase-producing $B$. fragilis $\mathrm{N}-17$, B. distasonis $\mathrm{N}-1$, and $B$. thetaiotaomicron $\mathrm{N}-79$, maintained in our department, which exhibited potent pathogenicity in a previous guinea pig intracutaneous infection study ${ }^{8}$. E. coli MCO 85036 isolated from a sputum sample preserved in our department was used as a representative aerobic microbe.

2. Animals

Female Hartley white guinea pigs weighing $350-400 \mathrm{~g}$ were used.

3. Bacterial inoculation

The anaerobes were incubated on GAM agar medium (Nissui Pharmaceutical Co., Ltd., Tokyo, Japan) in an anaerobic chamber (Forma Scientific, Inc., Marietta, Ohio, USA) at $37^{\circ} \mathrm{C}$ for $48 \mathrm{hr}$. E. coli was incubated aerobically on Mueller-Hinton agar medium (MH agar medium, Becton Dickinson Microbiology Systems, Cockeysville, Md, USA) at $37^{\circ} \mathrm{C}$ for $18 \mathrm{hr}$. The resulting colonies were suspended in $5 \mathrm{ml}$ of sterilized physiological saline, washed and centrifuged at $1,400 \times \mathrm{g}$, for $10 \mathrm{~min}$. The sediment of bacteria was resuspended in $3 \mathrm{ml}$ of physiological saline containing $5 \%$ mucin (Difco Laboratories, Detroit, Mich, USA), and adjusted to final concentrations of $10^{10}, 5 \times 10^{9}, 10^{8}, 5 \times 10^{7}, 10^{6}$ and $5 \times 10^{5} \mathrm{cfu} / \mathrm{ml}$ by using a spectrophotometer (UV-120-01, Shimadzu Seisakusho, Kyoto, Japan) calibrated in advance for counting bacteria. The inoculum size and six combinations of anaerobic/aerobic bacteria inoculated are shown in Table 1. The volume of inoculation was $0.2 \mathrm{ml}$.

Lung inoculation was performed by tracheal infusion using a modified version of Kannangara's method $^{9 !}$. Guinea pigs were anesthetized by intraperitoneal injection of $1.0 \mathrm{ml}$ of a mixture of $10 \mathrm{ml}$ of a solution of $500 \mathrm{mg}$ of ketamine hydrochloride (Ketalar $50^{\circledR}$, Sankyo Company, Ltd., Tokyo, Japan) and 1.25 $\mathrm{ml}$ of $2 \%$ xyladine hydrochloride (Ceractal ${ }^{\circledR}$, Bayer Ltd., Tokyo), and were disinfected with povidone iodine (10\% Isodine ${ }^{\circledR}$ solution, Meiji Seika Kaisha, Ltd., Tokyo) from the neck to the abdomen. The trachea was exposed by median incision of the neck, and punctured with a 23-G disposable venular needle (Top Company, Ltd., Tokyo); the outer tube was then advanced into the distal bronchial tree of the right lung. A sterilized syringe containing the bacterial suspension was connected to the outer tube, and $0.2 \mathrm{ml}$ was slowly infused into the bronchus, after which the outer tube was extracted, and the puncture hole was sutured.

4. Evaluation of lung lesions

The lung lesions were evaluated immediately after death. The surviving animals were killed on the 7 th day after infusion of the bacterial suspension. After gross examination, the right lung was aseptically removed, and a part of it was fixed with formalin for histopathologic examination. Another part was homogenized in $1 \mathrm{ml}$ of sterile physiological saline, diluted serially with saline, cultured on GAM agar medium for anaerobes or MH agar medium for aerobes, and bacterial counts were determined.

Lung lesions were scored according to the severity of inflammation on a scale of $0 \sim 7$ as follows: 0 for normal; 1 for a condition in which few neutrophils are observed, and aeration of the alveolar space is almost completely retained despite thickening of the alveolar wall due to edema; 2 for milder inflammation in which fewer inflammatory cells are observed, but effusion is present in the alveolar space; 3 for severe inflammation in which the alveolar wall is thickened due to edema, and the alveolar space is filled with inflammatory effusion. Two points each were added for abscesses and pleuritis. This made the maximum score 7.

5. Measurement of the redox potential (Eh)

The Eh was measured in right lung tissue by a potentiometer (No. 6029, Horiba Seisakusho, Kyoto) immediately after thoracotomy. 
6. Analysis by chemotherapy

(1) Antibiotics and bacterial strains

Clindamycin (CLDM, Japan Upjohn Ltd., Tokyo) and aztreonam (AZT, Eisai Company, Ltd., Tokyo) were used for inhibition and treatment of developing pneumonia in guinea pigs infected with $B$. fragilis N-17 $\left(10^{9} \mathrm{cfu}\right)$ and E. coli MCO $85036\left(10^{7} \mathrm{cfu}\right)$. The minimal inhibitory concentrations (MICs) of CLDM and AZT against $B$. fragilis $\mathrm{N}-17$ were $0.05 \mu \mathrm{g} / \mathrm{ml}$ and $>100 \mu \mathrm{g} / \mathrm{ml}$, respectively, and those against $E$. coli $\mathrm{MCO}$ 85036 were $50 \mu \mathrm{g} / \mathrm{ml}$ and $0.025 \mu \mathrm{g} / \mathrm{ml}$, respectively.

(2) Chemotherapy

After a mixture of $B$. fragilis and $E$. coli was infused into the guinea pig trachea, the animals were divided into 4 groups consisting of 6-15 animals each: A control group not given any antibiotics, an AZT group, a CLDM group, and an AZT + CLDM group. The dose of CLDM was $12 \mathrm{mg}$ and that of AZT was 10 mg per animal. The antibiotics were administered intraperitoneally immediately after inoculation of the bacteria, thereafter every $12 \mathrm{hr}$ for 4 days, and every $24 \mathrm{hr}$ for the final 3 days. As is previously mentioned, the animals were killed after 7 days and lung lesions were evaluated.

(3) Serum and lung tissue concentrations of antibiotics

Three animals in each group were given both AZT (10 mg) and CLDM (12 mg) intraperitoneally. They were sacrified $30 \mathrm{~min}$ and 1,2, 4, 6 and $8 \mathrm{hr}$ after administration, and their blood was collected. Lungs were removed and homogenized in $0.1 \mathrm{M}$ phosphate buffer, $\mathrm{pH}$ 7.4, and the AZT and CLDM concentrations were determined by bioassays using E. coli ATCC 27166 and Micrococcus luteus ATCC 6638, respectively, as indicator strains ${ }^{10)}$.

7. Neutrophil phagocytosis

The rates of phagocytosis of $B$. fragilis $\mathrm{N}-17$ and $E$. coli MCO 85036 by neutrophils were determined by the method of Hasui et al. ${ }^{11)}$ using blood from 5 healthy human adults ( 2 males and 3 females) aged $25 \sim 32$ years. Bacteria grown on the appropriate agar medium were suspended in physiological saline, washed 3 times, adjusted to $10^{9} \mathrm{cfu} / \mathrm{ml}$, and stained for $30 \mathrm{~min}$ with $5 \%$ propidium iodide (PI; Sigma Chemical Co., St., Louis, Mo, USA) solution. The percent phagocytosis was calculated by flow cytometry (FACScan ${ }^{\circledR}$; Becton Dickinson Co., San Jose, Calif., USA).

The culture filtrates of B. fragilis in GAM broth (Nissui Pharmaceutical Co., Ltd., Tokyo) and of E. coli in Mueller-Hinton broth (MHB: Difco) incubation at $37^{\circ} \mathrm{C}$ for $24 \mathrm{hr}$ were sterilized by passage through a Millipore filter $(0.22 \mu \mathrm{m}$, Nihon Millipore Ltd., Tokyo), a $100 \mu \mathrm{l}$ of the filtrate was added to $200 \mu \mathrm{l}$ of a mixture of whole blood and PI-stained bacterial suspension, and the percent phagocytosis was determined. The $\mathrm{pH}$ of each broth suspension was adjusted to that of the culture filtrate with $0.1 \mathrm{~N} \mathrm{HCl}$, and the percent phagocytosis was similarly determined for the control.

8. Statistics

The differences between groups were tested for significance by the unpaired Student's $t$-test, and the results were expressed as the mean and standard deviation.

\section{Results}

1. Findings of lung inflammation in single bacterial infection

As shown in Table 1, no deaths were occurred in the groups inoculated with a single bacterial strain, although pneumonia was observed in all animals inoculated with $10^{9} \mathrm{cfu}$ of each bacterium. Abscess formation was noted in 2 of the 6 animals inoculated with $B$. fragilis at $10^{9} \mathrm{cfu}$ and in 1 of the 6 animals inoculated with $E$. coli at $10^{9} \mathrm{cfu}$. Pleural damage was observed in the animals inoculated with $B$. fragilis at $10^{9} \mathrm{cfu}$ and $B$. distasonis at $10^{9} \mathrm{cfu}$, but none was noted in any $E$. coli group. Among the groups inoculated with anaerobic bacteria, the lung lesion score was the highest in the $B$. fragilis group at $10^{9} \mathrm{cfu}$ (score 3.33 
Table 1 Findings in the lung of guinea pigs on the seven days after infection

\begin{tabular}{|c|c|c|c|c|c|c|}
\hline Bacteria $^{\text {a) }}$ & $\begin{array}{c}\text { Inoculum size } \\
\left(\mathrm{cfu}^{\mathrm{b})}\right)\end{array}$ & $\begin{array}{c}\text { No. of } \\
\text { guinea pigs }\end{array}$ & $\begin{array}{c}\text { Mortalityc) } \\
(\mathrm{n})\end{array}$ & $\underset{(\mathrm{n})}{\stackrel{P}{\text { Pneumonia }}}$ & $\begin{array}{c}\text { Abscess } \\
\text { formation(n) }\end{array}$ & $\begin{array}{c}\text { Pleuritis } \\
(\mathrm{n})\end{array}$ \\
\hline \multicolumn{7}{|l|}{ Single infection } \\
\hline \multirow[t]{2}{*}{$B . f$} & $10^{9}$ & 6 & 0 & $6 / 6$ & $2 / 6$ & $4 / 6$ \\
\hline & $10^{7}$ & 6 & 0 & $2 / 6$ & 0 & 0 \\
\hline B.d & $10^{9}$ & 4 & 0 & $4 / 4$ & 0 & $2 / 4$ \\
\hline B.t & $10^{9}$ & 4 & 0 & $4 / 4$ & 0 & 0 \\
\hline \multirow[t]{3}{*}{ E.c } & $10^{9}$ & 6 & 0 & $6 / 6$ & $1 / 6$ & 0 \\
\hline & $10^{7}$ & 6 & 0 & $5 / 6$ & 0 & 0 \\
\hline & $10^{5}$ & 4 & 0 & $2 / 4$ & 0 & 0 \\
\hline \multicolumn{7}{|l|}{ Mixed infection } \\
\hline \multirow[t]{3}{*}{ B.f/E.c } & $10^{9} / 10^{7}$ & 6 & $4 / 6$ & $6 / 6$ & $6 / 6$ & $6 / 6$ \\
\hline & $10^{9} / 10^{5}$ & 6 & 0 & $6 / 6$ & $2 / 6$ & $2 / 6$ \\
\hline & $10^{7} / 10^{7}$ & 6 & 0 & $6 / 6$ & 0 & 0 \\
\hline B.d/E.c & $10^{9} / 10^{7}$ & 6 & $2 / 6$ & $6 / 6$ & $4 / 6$ & $2 / 6$ \\
\hline B.t/E.c & $10^{9} / 10^{7}$ & 6 & 0 & $6 / 6$ & 0 & 0 \\
\hline \multicolumn{7}{|c|}{$\begin{array}{l}\text { a) B.f: Bacteroides fragilis } \mathrm{N}-17, \text { B.d:B. distasonis } \mathrm{N}-1 \text {, } \\
\text { B.t: B. thetaiotaomicron N-79, E.c : Escherichia coli } \mathrm{MCO} 85036 \\
\text { b) cfu: colony forming unit }\end{array}$} \\
\hline
\end{tabular}

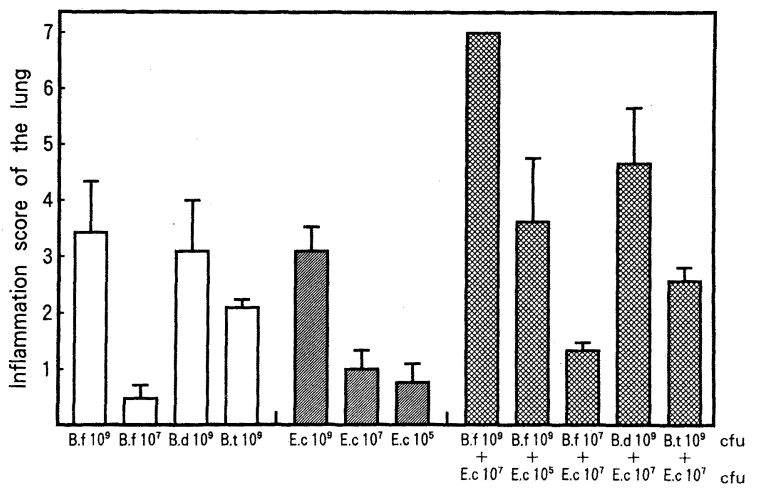

\pm 0.9 ), followed by the $B$. distasonis group at $10^{9} \mathrm{cfu}$, and the $B$. thetaiotaomicron group at $10^{9} \mathrm{cfu}$. Among the groups inoculated with $E$. coli, inflammation was the severest at $10^{9} \mathrm{cfu}$ (score $3.0 \pm 0.4$ ), with milder changes at $10^{7}$ and $10^{5} \mathrm{cfu}$ (Fig. 1).

2. Features of lung inflammation induced by mixed infection

As shown in Table 1 and Fig. 1, in the group inoculated concomitantly with B. fragilis at $10^{9} \mathrm{cfu}$ and $E$. coli at $10^{7} \mathrm{cfu}, 4$ of the 6 animals died within 7 days, and marked pneumonia and pleuritis were noted in all the animals (score 7.0). In the group concomitantly inoculated with B. fragilis at $10^{9} \mathrm{cfu}$ and $E$. coli at $10^{5}$ $\mathrm{cfu}$, no deaths occurred, but pneumonia was noted in all animals, and abscess formation in 2 and pleuritis in 2 of the 6 animals (score $3.5 \pm 1.1$ ). In the group inoculated with $B$. fragilis at $10^{7} \mathrm{cfu}$ and $E$. coli at $10^{7} \mathrm{cfu}$, pneumonia only was demonstrated in all the animals (score $1.13 \pm 0.2$ ). In the group inoculated with $B$. distasonis at $10^{9} \mathrm{cfu}$ and $E$. coli at $10^{7} \mathrm{cfu}, 2$ of the 6 animals died, pneumonia was marked, and abscess and pleuritis was demonstrated in 2 (score $4.5 \pm 0.9$ ). In the group inoculated with $B$. thetaiotaomicron at $10^{9} \mathrm{cfu}$ and $E$. coli at $10^{7} \mathrm{cfu}$, lung lesions were relatively mild (score $2.5 \pm 0.2$ ). The score was generally higher in 
Table 2 Redox potentials of the lungs of guinea pigs infected with $B$. fragilis and/or E. coli

\begin{tabular}{|c|c|c|c|c|c|c|c|c|c|}
\hline \multirow{2}{*}{ Score ${ }^{a)}$} & \multicolumn{8}{|c|}{ Redox potential $(\mathrm{mV}$, mean $\pm \mathrm{SD})$} & \\
\hline & B. fragilis $^{\text {b) }}$ & $s^{b)} \quad(n)$ & \multicolumn{2}{|c|}{ E. $\operatorname{coli}^{\mathrm{c})}$} & $(\mathrm{n})$ & Mixed $^{\text {d) }}$ & \multicolumn{3}{|c|}{ (n) } \\
\hline $0 \sim 1$ & $-42.6 \pm 77$ & $(7)_{7 e)}$ & $-10.8 \pm 54$ & (5) & & $-66.8 \pm 30$ & (5) & & \\
\hline $2 \sim 4$ & $-180 \pm 23$ & $(3)^{e}$ & $-56 \pm 16$ & (6) & & $-150.8 \pm 43$ & (12) & & f) \\
\hline $5 \sim 7$ & $-205 \pm 10$ & (2) & $-68(1)$ & & & $-235.3 \pm 51$ & (11) & f) & \\
\hline
\end{tabular}

a) The scores were explained in the text.

b) The lungs infected with $B$. fragilis $\mathrm{N}-1710^{9} \mathrm{cfu}(\mathrm{n}=6)$ and $10^{7} \mathrm{cfu}(\mathrm{n}=6)$.

c) The lungs infected with E. coli MCO $8503610^{9} \mathrm{cfu}(\mathrm{n}=6)$ and $10^{7} \mathrm{cfu}(\mathrm{n}=6)$.

d) The lungs infected with $B$. fragilis group $10^{9} \sim 10^{7}$ cfu and $E$. coli $\mathrm{MCO}$ $8503610^{7} \sim 10^{5} \mathrm{cfu}(\mathrm{n}=28)$.

e) $\mathrm{p}<0.05, \quad{ }^{\mathrm{f})} \mathrm{p}<0.01$

Table 3 Bacterial recovery from the lung of guinea pigs infected with $B$. fragilis $10^{9} \mathrm{cfu}$ and $E$. coli $10^{7} \mathrm{cfu}$ alone or in combination on day 7

\begin{tabular}{|c|c|c|c|c|c|}
\hline \multirow[b]{2}{*}{ Bacteria $^{\text {a) }}$} & \multirow{2}{*}{$\begin{array}{l}\text { Inoculum size } \\
(\mathrm{cfu})\end{array}$} & \multirow{2}{*}{$\begin{array}{c}\text { No. of } \\
\text { guinea pigs (n) }\end{array}$} & \multicolumn{3}{|c|}{ Bacterial recovery $(n)$} \\
\hline & & & $\begin{array}{l}\text { B. fragilis } \\
\text { alone }\end{array}$ & $\begin{array}{l}E . \text { coli } \\
\text { alone }\end{array}$ & $\begin{array}{l}\text { B. fragilis } \\
\text { and E. coli }\end{array}$ \\
\hline B. fragilis & $10^{9}$ & 6 & 0 & 0 & . \\
\hline E. coli & $10^{7}$ & 6 & 0 & 0 & - \\
\hline $\begin{array}{l}\text { B. fragilis } \\
\text { E. coli }\end{array}$ & $\left.\begin{array}{l}10^{9} \\
10^{7}\end{array}\right\}$ & 6 & $1^{\text {b) }} / 6$ & $3^{\text {c) }} / 6$ & $1^{\text {d) } / 6}$ \\
\hline $\begin{array}{l}\text { a) } \text {. fragilis } \\
\text { Limit of v } \\
\text { b) The viable } \\
\text { c) The viable } \\
\text { d) The viable }\end{array}$ & $\begin{array}{l}\text { Bacteroides fragil } \\
\text { ble count of bact } \\
\text { count of } B \text {. fragil } \\
\text { count of } E \text {. coli } \\
\text { count of } B \text {. fragil }\end{array}$ & $\begin{array}{l}\text { lis N-17, E. coli } \\
\text { teria is }<10^{2} \mathrm{cfu} / \\
\text { lis was } 3.5 \times 10^{6} \mathrm{cf} \\
\text { was } 1.5 \times 10^{6}, 5.1> \\
\text { lis } / \text { E. coli was } 3.1\end{array}$ & $\begin{array}{l}\text { Escherichia cc } \\
\text { u/g. } \\
10^{5}, 9.8 \times 10^{3} \\
\times 10^{5} / 2.8 \times 10\end{array}$ & g, and a & $\begin{array}{l}\text { imals died. } \\
\text { nimal died. }\end{array}$ \\
\hline
\end{tabular}

the mixed infection groups than in the single infection groups, being the highest in the group inoculated with $B$. fragilis at $10^{9} \mathrm{cfu}$ and $E$. coli at $10^{7} \mathrm{cfu}$.

3. Local Eh of the lung

As shown in Table 2 , the Eh value was -68 to $+60 \mathrm{mV}$ in lungs infected with $E$. coli, and no correlation was observed between the severity of pneumonia and Eh. In the B. fragilis single infection groups, Eh tended to decrease as the severity of the pneumonia increased, and at the same score it tended to be lower in the mixed infection groups than in the single infection ones.

4. Recovery of bacteria

The counts of viable bacteria from lung lesions are shown in Table 3. In the groups inoculated with $E$. coli or $B$. fragilis alone, clearance of bacteria from the lung was complete. In the mixed infection groups, the bacteria were recovered from some animals, all of which died except one from the B. fragilis recovered animals.

5. Analysis of mixed infection groups by chemotherapy

As shown in Table 4, the concentration of AZT exceeded its MIC against $E$. coli for $6 \mathrm{hr}$ in the serum and for $1 \mathrm{hr}$ in lung tissue, but the level was less than its MIC against $B$. fragilis. Conversely, the concentration of CLDM exceeded its MIC against $B$. fragilis for $6 \mathrm{hr}$ in the serum and for $8 \mathrm{hr}$ in the lung tissue, but it was less than its MIC against $E$. coli. Two (18\%) of the 11 animals treated with CLDM died, but no deaths occurred in the animals treated with AZT or AZT + CLDM (Table 5). The lung lesion scores 
Table 4 Mean serum and lung tissue concentrations of aztreonam (AZT) and clindamycin (CLDM) in three guinea pigs injected intraperitoneally

\begin{tabular}{|c|c|c|c|c|c|c|c|}
\hline \multicolumn{2}{|c|}{ Antibiotics $^{\text {a) }}$} & \multicolumn{6}{|c|}{$\begin{array}{c}\text { Levels of antibiotics in serum }(\mu \mathrm{g} / \mathrm{ml}) \text { and lung tissue }(\mu \mathrm{g} / \mathrm{g}) \\
\text { at indicated time }(\mathrm{h}) \text { after injection }\end{array}$} \\
\hline & & 0.5 & 1 & 2 & 4 & 6 & 8 \\
\hline \multirow{2}{*}{$\mathrm{AZT}$} & Serum & 38.3 & 23.9 & 2.33 & 0.46 & 0.05 & $<0.03$ \\
\hline & Lung & 0.88 & 0.58 & $<0.01$ & $<0.01$ & $<0.01$ & $<0.01$ \\
\hline \multirow{2}{*}{ CLDM } & Serum & 1.78 & 0.85 & 0.5 & 0.18 & 0.11 & $<0.03$ \\
\hline & Lung & 7.67 & 5.81 & 5.0 & 1.77 & 1.58 & 1.1 \\
\hline
\end{tabular}

a) Dose : AZT 10mg/animal, CLDM 12mg/animal

Table 5 Findings in the lung of guinea pigs concomitantly infected with $B$. fragilis $\mathrm{N}-17$ at $10^{9}$ cfu and E. coli MCO 85036 at $10^{7}$ cfu after 7 days of antibiotic administration

\begin{tabular}{cccccc}
\hline Antibiotics $^{\text {a) }}$ & $\begin{array}{c}\text { No. of } \\
\text { guinea pigs }\end{array}$ & $\begin{array}{c}\text { Mortality } \\
(\mathrm{n})\end{array}$ & $\begin{array}{c}\text { Pneumonia } \\
(\mathrm{n})\end{array}$ & $\begin{array}{c}\text { Abscess } \\
(\mathrm{n})\end{array}$ & $\begin{array}{c}\text { Pleuritis } \\
(\mathrm{n})\end{array}$ \\
\hline None & 6 & $4 / 6$ & $6 / 6$ & $6 / 6$ & $6 / 6$ \\
\hline AZT & 9 & 0 & $9 / 9$ & $2 / 9$ & $1 / 9$ \\
CLDM & 11 & $2^{\text {b) }} / 11$ & $11 / 11$ & $3 / 11$ & $2 / 11$ \\
AZT + CLDM & 15 & 0 & $10 / 15$ & 0 & 0 \\
\hline
\end{tabular}

a) AZT : aztreonam. CLDM : clindamycin.

Treatment schedule is shown in the text.

b) The dead animals were autopsied and evaluated immediately.

Table 6 Bacterial recovery from the lung of guinea pigs concomitantly infected with $B$. fragilis $\mathrm{N}-17$ at $10^{9} \mathrm{cfu}$ and $E$. coli $\mathrm{MCO} 85036$ at $10^{7} \mathrm{cfu}$ after 7 days of antibiotic administration

\begin{tabular}{ccccc}
\hline \multirow{2}{*}{ Antibiotics $^{\text {a) }}$} & \multirow{2}{*}{$\begin{array}{c}\text { Guinea pigs } \\
\end{array}$} & & \multicolumn{3}{c}{ Bacterial recovery $^{\mathrm{b})}(\mathrm{n})$} \\
\cline { 3 - 5 } & 6 & B. fragilis alone & E. coli alone & B. fragilis and $E$. coli \\
\hline none $^{\mathrm{c})}$ & 6 & $1 / 6$ & $3 / 6$ & $1 / 6$ \\
\hline $\mathrm{AZT}$ & 9 & $3^{\mathrm{d})} / 9$ & 0 & 0 \\
$\mathrm{CLDM}$ & 11 & $1^{\mathrm{e}} / 11$ & $2^{\mathrm{f}} / 11$ & $\left.1^{\mathrm{g}}\right) / 11$ \\
$\mathrm{AZT}+\mathrm{CLDM}$ & 15 & 0 & 0 & 0 \\
\hline
\end{tabular}

a) AZT : aztreonam, CLDM : clindamycin. The treatment schedule is shown in the text.

b) Isolates positives $(\mathrm{n}) /$ number of guinea pigs inoculated.

c) The viable count of bacteria is shown in Table 3 .

d) The viable count of $B$. fragilis was $1.3 \times 10^{3}, 2.2 \times 10^{4}$ and $4.4 \times 10^{2} \mathrm{cfu} / \mathrm{g}$.

e) The viable count of $B$. fragilis was $5.9 \times 10^{4} \mathrm{cfu} / \mathrm{g}$.

f) The viable count of $E$. coli was $2.5 \times 10^{3}$ and $2.9 \times 10^{3} \mathrm{cfu} / \mathrm{g}$, of which the one animal died.

g) The viable count of $B$. fragilis $/ E$. coli was $5.8 \times 10^{3} / 1.6 \times 10^{6} \mathrm{cfu} / \mathrm{g}$, and the animal died.

were $3.0 \pm 2.1$ in the CLDM group, $2.6 \pm 1.9$ in the AZT group, and $1.3 \pm 0.5$ in the AZT + CLDM group, the latter being the lowest (Fig. 2). No bacteria were recovered from the lungs in the AZT + CLDM group. In the AZT group, $B$. fragilis was recovered from 3 of the 9 animals. In the CLDM group, $B$. fragilis was recovered from $1, E$. coli from 2 and both from 1 of the 11 animals (Table 6). The viable counts are shown in the footnote to Table 6 . 

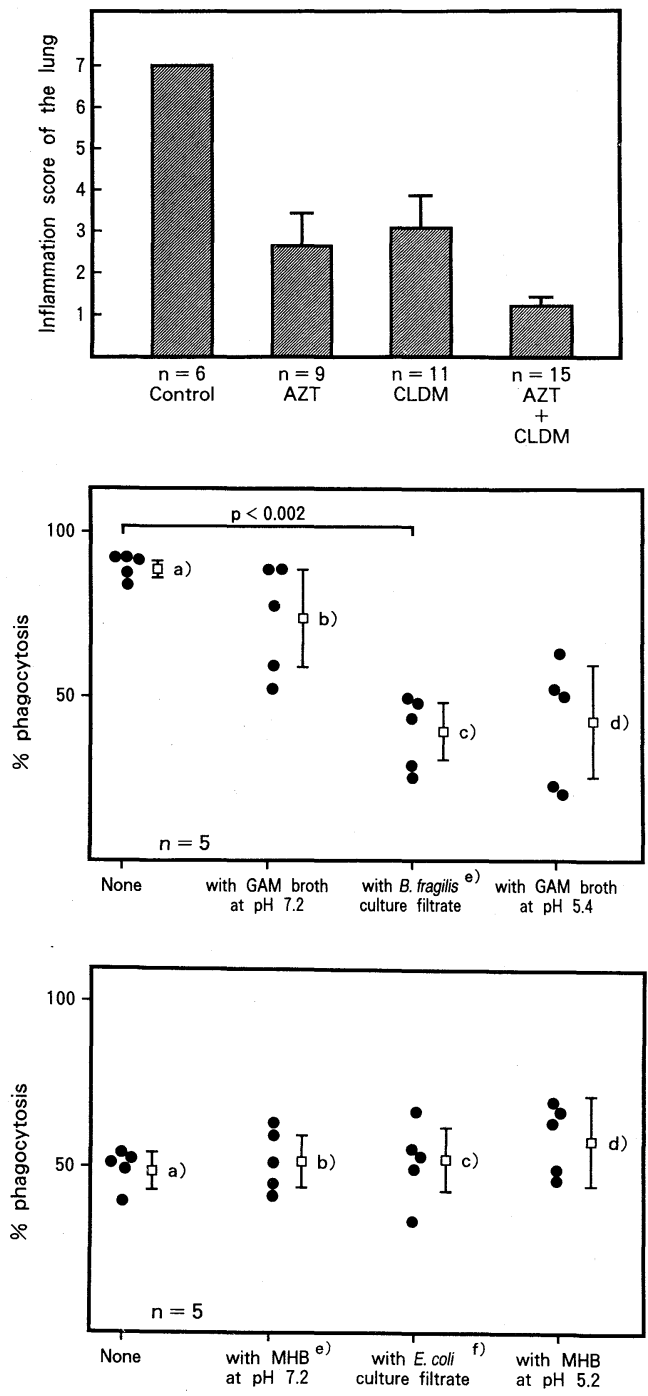

Fig. 2 Findings in the lungs of guinea pigs concomitantly infected with $B$. fragilis $\mathrm{N}-1710^{9} \mathrm{cfu}$ and $E$. coli MCO $8503610^{7} \mathrm{cfu}$, after antibiotic treatment. AZT: aztreonam; CLDM: clindamycin. The treatment schedule is shown in the text.

Fig. 3 Effect of $B$. fragilis $\mathrm{N}-17$ culture filtrate on phagocytosis of $E$. coli MCO 85036 by human neutrophils. \% phagocytosis (mean \pm SD): a) 89.3 \pm 3.3 , b) $74.8 \pm 15.2$, c) $40.2 \pm 9.6$, d) $42.6 \pm 17.1$, e) The $\mathrm{pH}$ of the $B$. fragilis culture filtrate was 5.4 .

6. Interaction between $B$. fragilis and $E$. coli in human neutrophil phagocytosis

The percent phagocytosis of $E$. coli $(89.3 \pm 3.3 \%)$ by human neutrophils was significantly higher than that of $B$. fragilis $(49.2 \pm 5.7 \%, \mathrm{p}<0.002)$. The percent phagocytosis of $E$. coli showed no significant changes when GAM broth (pH 7.2) was added, but it was significantly reduced when the culture medium of $B$. fragilis ( $\mathrm{pH} 5.4$ ) or GAM broth adjusted to $\mathrm{pH} 5.4$ was added ( $\mathrm{p}<0.002$, Fig. 3). The percent phagocytosis of B. fragilis was not affected significantly by the addition of $\mathrm{MHB}(\mathrm{pH} 7.2)$ culture medium of $E$. coli ( $\mathrm{pH} 5.2$ ), or MHB adjusted to $\mathrm{pH} 5.2$ (Fig. 4).

\section{Discussion}

There has been no established model of anaerobic bacterial infection of the lung in animals. Kannangara et al.9) inoculated rabbits with various anaerobic bacteria by tracheal infusion, and reported that lung abscesses could be produced by anaerobic bacteria isolated from the oral cavity. Using this method, we infected female Hartley guinea pigs by tracheal infusion of $E$. coli and three B. fragilis group 
organisms (B. fragilis, B. distasonis, and B. thetaiotaomicron) alone or in combination, and the interaction between aerobic and anaerobic bacteria in lung infections was investigated. $E$. coli and $B$. fragilis strains are not very common pathogens in community-acquired lung infections, but they are often responsible for secondary lung infections in patients with severe underlying diseases ${ }^{212113)}$.

In the animals infected with $E$. coli alone, pneumonia was more notable than pleural lesions. On the other hand, in most animals infected with $B$. fragilis and $B$. distasonis, marked cell infiltration and tissue damage were noted in the visceral pleura, although the pneumonia was milder. Abscess formation was noted in about one-third of the animals inoculated with $B$. fragilis, and marked inflammation was observed around the abscesses and peripheral lung regions. Thus, the main lung lesions induced by $E$. coli and $B$. fragilis are considered to be different. One possible reason for this difference may be that peripheral lung regions, in which aeration is reduced by inflammatory effusion and secretion, is advantageous for anaerobic bacteria. In the animals infected with a single bacterial species, no bacteria were recovered from the lungs 7 days after inoculation despite findings of pneumonia, abscess formation, and pleuritis. Thereby, lung inflammation is considered to be established early after inoculation, and bacteria to have been cleared by alveolar macrophages, airway cilia, and other physiologic protective mechanisms of the lung. Out of the three Bacteroides species, B. fragilis was the most virulent. The inflammatory findings in the mixed infection groups were more severe than those in the single infection ones.

In the group infected with $B$. fragilis at $10^{9} \mathrm{cfu}$ and $E$. coli at $10^{7} \mathrm{cfu}$, inflammatory findings were markedly stronger than those in other mixed infection groups, deaths were observed within the first 4 days after infection, and $E$. coli was recovered from the lungs, but $B$. fragilis was never detected alone. The Eh values in the lung lesions were mostly- $100 \mathrm{mV}$ or less in animals of the mixed infection group in which the inflammation score was 2 or above, suggesting that the foci of inflammation were in the anaerobic environment advantageous for $B$. fragilis. In the antibiotic chemotherapy study, neither bacterial species was recovered and inflammation was the mildest in the animals treated with AZT + CLDM. In those treated with AZT, E. coli was not recovered, but $B$. fragilis, which is resistant to the drug, was recovered, and lung lesions were accompanied by abscesses and pleuritis, which were considered to have been primarily caused by $B$. fragilis. In animals given CLDM. E. coli and B. fragilis persisted in some, and lung lesions were the most severe, suggesting that $E$. coli might synergistically act with $B$. fragilis. Synergism between anaerobic and aerobic bacteria was shown by the intra-abdominal infection study of Weinstein et $\mathrm{al}^{6}{ }^{6}$. They explained the process of the mixed infection as a biphasic infection ${ }^{414145)}$. In the present study, $E$. coli was primarily responsible for pneumonia, and abscesses and pleuritis were notable among lung lesions induced by $B$. fragilis. However, it was uncertain whether this clearly demonstrated the biphasic theory. Further studies are needed concerning this phenomenon. The phagocytic activity of human neutrophils against $E$. coli was significantly reduced by the addition of the culture filtrate of $B$. fragilis (the $\mathrm{pH}$ of this culture medium was approximately 5.2-5.4). Rotstein et al. ${ }^{16)}$ reported that neutrophil phagocytosis and superoxide production are markedly suppreseed by the metabolism of anaerobic bacteria. Since $B$. fragilis was less susceptible to neutrophil phagocytosis than $E$. coli, mixed infections caused by the two organisms are considered to enhance the pathogenicity of $B$. fragilis as well as of $E$. coli by facilitating the survival of $B$. fragilis at the foci of inflammation in the lung and reducing neutrophil phagocytosis of $E$. coli. This study suggests that $E$. coli and $B$. fragilis interact synergistically in the lung as well as in intra-abdominal infection, with anaerobic bacteria enhancing the pathogenicity of aerobic bacteria.

\section{Acknowledgments}

I would like to thank Miss Masumi Ikuta and Miss Hatsumi Kuroki for their technical assistance, and doctors of the respiratory study group, Second Department of Internal Medicine, Oita Medical University, for their cooperation. 


\section{References}

1) Finegol, S.M.: General aspects of anaerobic infection. In Anaerobic infections in humans. (Finegold, S.M. and George, W.L. ed.) p. 137-153, Academic Press, San Diego, California, 1989.

2) Bartlett, J.G.: Anaerobic bacterial infections of the lung. Chest 91: 901-909, 1987.

3) Miyazaki, S., Ishii, T., Tsuji, A., Kitaya, S., Kaneko, Y., Ogawa, M. \& Goto, S.: Pathogenic factors in mixed infection due to Bacteroides fragilis and other species of bacteria in mice. Jap. J. Bacteriol. 41: 611-617, 1986.

4) Gorbach, S.L.: Interactions between aerobic and anaerobic bacteria. Scand. J. Infect. Dis. 31 (Suppl.): 61-67, 1982.

5) Onderdonk, A.B., Cisneros, R.L., Finberg, R.W., Crabb, J.H. \& Kasper, D.L.: Animal model system for studying virulence of and host response to Bacteroides fragilis. Rev. Infect. Dis. 12: s169-177, 1990.

6) Weinstein, W.M., Onderdonk, A.B., Bartlett, J.G. \& Gorbach, S.L.: Experimental intra-abdominal abscesses in rats: Development of an experimental model. Infect. Immun. 10: 1250-1255, 1974.

7) Maskell, J.P.: The pathogenicity of Bacteroides fragilis and related species estimated by intracutaneous infection in the guinea pig. J. Med. Microbiol. 14: 131-140, 1981.

8) Nasu, M., Goto, J., Goto, Y., Tashiro, T.\& Akashi, M.: An evaluation of the pathogenicity of Bacteroides fragilis in the intracutaneous infection of the guinea pig. J.J.A. Inf. D, 58: 512-517, 1984.

9) Kannangara, D.W., Thadopacci, H., Bach, V.T. \& Webb, D.: Animal model for anaerobic lung abscess. Infect. Immun. 31: 592-597, 1981.

10) Edberg, S.C.: The measurement of antibiotics in human body fluids: Techniques and significance. In Antibiotics in laboratory medicine 2nd ed. (Lorian, V. ed.) p. 381-476, Williams \& Wilkins, Baltimore, MD, 1986.

11) Hasui, M., Hirabayashi, Y. \& Kobayashi, Y.: Simultaneous measurement by flow cytometry of phagocytosis and hydrogen peroxide production of neutrophils in whole blood. J. Immunol. Methods 117: 53-58, 1989.

12) Bartlet, J.G.: Respiratory tract and other thoracic infections. In Anaerobic infection in humans. (Finegold, S.M. and George, W.L. ed.) p. 311-331, Academic Press, San Diego, California, 1989.

13) Finergold, S.M.: Aspiration pneumonia, lung abscess, and empyema. In Respiratory infections: Diagnosis and management 2nd ed. (Pennington, J.E. ed.) p. 264-275, Raven Press, New York, 1989.

14) Onderdonk, A.B., Weinstein, W.M., Sullivan, N.M., Bartlett, J.G. \& Gorbach, S.L.: Experimental intra-abdominal abscesses in rats: Quantitative bacteriology of infected animals. Infect. Immun. 10: 1257-1259, 1974.

15) Onderdonk, A.B., Bartlett, J.G. Oouie, T., Sullivan-Seigler, N. \& Gorbach, S.L.: Microbial synergy in experimental infection-abdominal abscess. Infect. Immun. 13: 22-26, 1976.

16) Rotstein, O.D., Vittorini, T., Kao, J., McBurnei, M.I., Nasmith, P.E. \& Grinstein, S.: A Solube Bacteroides by product impair phagocytic killing of Escherichia coli by neutrophils. Infect. Immun. 57: 745-753, 1989. 
嫌気性菌性肺炎の成立に抢ける好気性菌と嫌気性菌の相互作用

\author{
大分医科大学第 2 内科 \\ 後藤純 \\ 現住所：国立大分病院呼吸器科
}

(平成 4 年 7 月 22 日受付)

(平成 4 年 10 月 20 日受理)

\section{要旨}

嫌気性菌性肺炎の成立に抢ける嫌気性菌と好気 性菌との相互作用を研究する目的で, Bacteroides fragilis グループの 3 菌種 (B. fragilis $\mathrm{N}-17, B$. distasonis N-1, B. thetaiotaomicron N-79) と喀 痰から分離された Escherichia coli MCO 85036の 単独菌沶よび混合菌液をモルモット気管内注入法 により接種し, 肺病変を観察した。B. fragilis グ ループのうち, B. fragilis が最も強い肺病変を惹 起させ, その病変部位は E. coliのそれとは異なり 胸膜近くにあり, 肺炎, 膿瘍, 胸膜炎がみられた。 B. fragilis $10^{9} \mathrm{cfu}$ と E. coli $10^{7} \mathrm{cfu}$ の混合感染 は, 単独菌感染よりも強い肺病変を示し, 炎症所 見の酸化還元電位は低下した $(\max :-330 \mathrm{mV})$.
混合感染による肺病変を aztreonamと clindamycin 投与による解析をしたところ, 肺病変は E. coliによるものが主体であり, B. fragilis は $E$. coli との共存によって炎症所見に残存し易くな り，炎症を惹起していることが推察された。ヒト 好中球によるE. coli 貪食率は, B. fragilis 培養濾 液の添加により有意に低くなり（ $\mathrm{p}<0.002 ）, B$. fragilis 貪食率は, E. coli 培養濾液の添加にて影 響を受けなかった。すなわち, B. fragilis による肺 病変は E. coli との共存下でより強い炎症像を示 し, B. fragilis は E. coli による肺病変を協力的に 助長させ, 主に膿瘍と胸膜炎を形成していること が示唆された。 